\title{
Research on Patent Protection of Business Model under the Background of Internet+
}

\author{
Zhide Zhou ${ }^{1,2, *}$, Chunxue $\mathrm{Li}^{1}$ \\ ${ }^{1}$ Guilin University of Electronic Technology, Intellectual Property School Guilin, Guangxi, China \\ ${ }^{2}$ Xiamen University Intellectual Property Research Institute Xiamen, Fujian, China
}

\begin{abstract}
Internet $+"$ is a disruptive technological innovation that brings unlimited possibilities for business model innovation. However, the lack of the patent protection system of the business model has hindered the innovation and development of the business model to a certain extent. From the perspective of the Internet + business model, this article briefly describes the current status and shortcomings of the protection of business model patents in China, and puts forward some thoughts and suggestions on establishing an Internet + business model to form a business model patent protection system.
\end{abstract}

\section{INTRODUCTION}

In September 2018, the State Council issued the "Opinions on Promoting the High-Quality Development of Innovation and Entrepreneurship and Creating an Upgraded Version of" Double Innovation ". Under the background of" Double Innovation ", Internet + has made great progress. Under the background of "Double Innovation", Internet + has made great progress. Androutsos[1]proposed that the deep integration of Internet technology and economic society has spawned new business models and business forms, showing spillover effects. In the situation where "Internet + " has become a new format, business model innovation has received unprecedented attention. Chen Shuyun, Tao Yunqing and others [2] found that "Internet +" promotes technological innovation through scale effect and competition effect, and builds an inclusive financial development index to stimulate the underlying social power and internal vitality to promote technological innovation[3]. According to the domestic and foreign situation, using the openness and scale effect of the Internet, product platformization, to study the influencing factors of the initial success of Chinese Internet companies Only excellent service value can have a chance to become a giant.

The business model involves various aspects such as finance and marketing. When applied by Internet companies, the business model becomes the result of the extension of the business management method in the business in combination with specific network technologies. The protection of objects provides a prerequisite.

\section{INTERNET+ BUSINESS MODEL}

\subsection{Business model overview}

The concept of "business model" first appeared in the late 1950s. It is a conceptual tool that contains many elements and the interaction between elements. It can be used to explain the business logic of a particular entity. The development of the concept of "business model" is closely linked to computer Internet technology and e-commerce, and its extension is constantly expanding. Can be granted a patent right. For Internet companies with e-commerce, information services, data services, online processing services, etc. as their main business, their business model is the same as their original concept. It is a product of the close integration of the Internet and various computer technologies, with very obvious technical characteristics. With the development of IT technology and the trend of the concept of "Internet +", business models with dual characteristics of management and technology are increasingly valued, and patents as a means of legal protection often become the first choice for enterprises to protect business models. However, due to the ambiguity of the status and standards of business model patents, as well as various objective factors in the specific process of patenting, it has hindered the patenting of the business model, thus preventing it from obtaining patent protection.

\subsection{Influence of Internet+ business model on business model innovation}

Business model innovation methods include disruptive innovation and gradual innovation. But no matter which innovation method is closely connected with the 
background of the times, Table 1 is the development and change process of the business model.

Table 1 Development history of business model innovation

\begin{tabular}{|c|c|c|c|c|}
\hline & $\begin{array}{c}\text { Period of origin } \\
1673-1969\end{array}$ & $\begin{array}{c}\text { Period of change } \\
1970-1989\end{array}$ & $\begin{array}{c}\text { Period of create } \\
1990-2001\end{array}$ & $\begin{array}{l}\text { Period of Internet+ } \\
2002 \text { to present }\end{array}$ \\
\hline Sales method & $\begin{array}{l}\text { Department store chain } \\
\text { Discount store }\end{array}$ & $\begin{array}{c}\text { Regional concentration } \\
\text { Directsales(Dell) } \\
\text { B2B e-commerce platform }\end{array}$ & $\begin{array}{l}\mathrm{C} 2 \mathrm{C} \text { e-commerce } \\
\text { platform } \\
\mathrm{B} 2 \mathrm{C} \text { e-commerce } \\
\text { platform }\end{array}$ & $\begin{array}{l}\text { Online+offline } \\
\text { omni-channel sales }\end{array}$ \\
\hline $\begin{array}{l}\text { Production } \\
\text { methods }\end{array}$ & IT Industry Cluster & $\begin{array}{l}\text { Fine production } \\
\text { Destock }\end{array}$ & $\begin{array}{l}\text { Professional } \\
\text { production }\end{array}$ & $\begin{array}{c}\text { Crowdsourcing } \\
\text { platform } \\
\text { Open innovation }\end{array}$ \\
\hline Funds & $\begin{array}{l}\text { Travel check } \\
\text { Credit card }\end{array}$ & Microfinance & $\begin{array}{l}\text { Micropayment } \\
\text { Third-payment } \\
\text { platform }\end{array}$ & $\begin{array}{l}\text { Crowdfunding } \\
\text { platform } \\
\text { Mobile terminal } \\
\text { payment }\end{array}$ \\
\hline Profit model & $\begin{array}{c}\text { "Blade+knife holder" } \\
\text { Consumable tying } \\
\text { Metering and printing } \\
\text { charges }\end{array}$ & $\begin{array}{c}\text { "Blade + knife holder" } \\
\text { transform(Low-cost } \\
\text { selling host }+ \text { high-priced } \\
\text { software,Nintendo) }\end{array}$ & $\begin{array}{l}\text { Portal Advertising } \\
\text { Search term ad }\end{array}$ & $\begin{array}{c}\text { Working circle } \\
\text { "match"'Advertising" } \\
\text { in the circle of friends }\end{array}$ \\
\hline
\end{tabular}

Now that we have entered the Internet + era, big data has penetrated into various industries. The impact of big data on traditional business models is mainly reflected in helping companies innovate, improve services and products, create new business models and make them the key to future enterprise competition.

There are foreign scholars [4-6] studying the interaction between technology patents and business method patents and the relationship with the market. Due to the rapid development of Internet+, the sharing, openness, exclusivity and monopoly of big data coexist New technologies are constantly evolving, and different industries are constantly infiltrating, and business model innovation shows endless vitality [7]. The Internet + business model has become the result of the extension of the business management method combined with specific network technologies in network commerce. At the same time, due to the rapid development of Internet + application technology, some industry competition companies, headhunting companies, etc. can obtain business secrets by means of big data calculation based on the relevant information that the company has disclosed. Under the current environment, it is difficult for companies to obtain compensation through legal channels. It can be said that under the background of Internet + , big data brings great opportunities to the development of enterprises, but at the same time, how to obtain intellectual property protection for business models and how to protect business secrets also pose new challenges.

\section{PROBLEMS IN THE PROTECTION OF BUSINESS MODEL PATENTS UNDER THE BACKGROUND OF INTERNET+}

The necessity analysis of business model patent protection shows that providing patent protection for business models has become a new development direction in the patent system. But even so, a series of problems inevitably exist in the specific examination practice of business model patents.

\subsection{The business model is unclear}

In the research of intellectual property rights, the word closest to the concept of "business model" is "business method patent", and in practice, the phenomenon of mixing the two often occurs, that is, business method patents and business models are replaced as synonyms. But the business model mentioned in this article is a broader concept. In general, business method patent refers to one or several ways of business model operation, and business model is a more abstract Business model concept.

\subsection{Lack of relevant specialized laws}

The current patent protection system in China mainly includes the "Patent Law", "Implementation Rules of the Patent Law" and "Guidelines for Patent Examination", but none clearly stipulates the patent object status of the business model. Due to the lack of special laws, in specific practical activities, companies and courts can only protect the business model through the fragmentary provisions in copyright law, trademark law, and anti-unfair competition law. First, from a copyright perspective, it is easy for competitors in an enterprise to use similar business models and provide the same products and services by changing the source code or modifying the appearance, while also avoiding infringement. Secondly, the Trademark Law focuses more on the protection of brand trademarks rather than the protection of business models of enterprises. Finally, from the perspective of unfair competition, in recent years, many cases have tried to protect the business model based on the "Anti-Unfair Competition Law", and pointed out that imitating the business model is a type of unfair competition and will damage the imitated The legitimate rights and interests of the main body of the business model. 


\subsection{Business model review standards are unscientific}

At present, the basis of object examination standards for patent applications in China is mainly Article 2 (2) of the Patent Law. The newly revised examination guidelines include business models containing technical solutions into the scope of protection of patent rights. It specifically stipulates the object examination standards for business model patents. Secondly, laws in China do not have specific provisions for the substantive review of business models. Compared with developed countries, the review criteria of the three elements of "creativity, novelty, and practicality" are too simple and general. In addition, the technical issues and supporting facilities related to business model patent examination are imperfect. These defects have also opened up a gap in the quantity and quality of business model patents between China and other developed countries to a certain extent.

\section{INTERNET+BUSINESS MODEL PATENT PROTECTION SYSTEM ASSUMPTION}

At present, China has introduced relevant policies to incorporate business models into the protection category of intellectual property objects, and many scholars have conducted research on the intellectual property protection system of business models [8], and all circles of the society have put forward some tentative suggestions.

The author believes that when constructing China's business model patent protection system, we must fully consider the current status of intellectual property protection in China. After clarifying the current status and problems of the protection of business model patents in the current law, combined with actual needs, the protection model of business model patents under the background of the Internet + business model can be improved from the following aspects:

\subsection{Clarify the definition of business model patents}

As mentioned earlier, the connection between business method patents and business models is extremely close, and there is a certain commonality between various business model innovations, but neither the economic community nor the legal community has yet made a relatively uniform and clear definition of it. Therefore, we must first define the business model patent so that it can be protected by the patent law. For example, "contains technical solutions and realizes various business activities and business activities. It is a kind of rules and methods for human social and economic activities." That is, it emphasizes that business models must include technical solutions. Use this to delineate the scope of the subject matter of patent protection for business models. The business model cannot be regarded as an object of intellectual property for protection as a whole.

\subsection{Improve relevant legislation}

In terms of legislation, we must first establish the object status of the patent right of the business model, and give it independence through clear legal provisions. In the "Patent Examination Guidelines", specific provisions can be made on the application of business model patents, clarifying the business model patent examination methods, object examination standards, substantive examination standards and examination procedures, etc. In exchange for the protection of the legislative spirit, and to ensure that business model patents can be effectively judicially protected if they are infringed.

\subsection{Improve business model patent examination standards and relevant examination regulations}

Due to problems such as overly general examination standards, unscientific examination methods, and lack of clear and specific relevant regulations, China should refine the examination standards for business model patents, establish a database for examination of business model patents, and improve relevant regulations:

First, the State Intellectual Property Office can revise the "Patent Examination Guidelines" or issue policy documents to standardize and refine issues related to business model patent applications. At the legislative level, you can design a separate chapter for business model patents in the Patent Examination Guide, starting with the definition of business model patents, and focusing on the particularity of business model patents, from examination logical relationships, examination method processes, object examination standards, and creativity Make special provisions on the review standards, etc., or list them separately to regulate.

Secondly, in the process of patent examination, when judging whether a business model patent belongs to the subject of patent protection, you can refer to the "dichotomy" examination ideas proposed in the "Examination Procedures and Substantive Examination Volume". Distinguish business models: If the claims involve computer and network technology, or other relevant technical features in the field, and not just simple business rules or business operation models, it can be determined that the business model in the patent application belongs to the scope of patent protection. Business model patents must contain computer and network technology, or other relevant technical features. Third, clarify the statutory standards for "novelty" and "creativeness" of business model patents to solve the problem of unclear business model patent examination standards. When judging the creativity of business model patents, different countries have different judgment ideas. The thinking of the American evaluation is: No matter whether it is the business model itself or the technical characteristics, as long as one meets the creative standard, the invention can be regarded as creative and the attitude is relatively loose. The European Union has a strict attitude. The creativity of business model patents must be reflected in the innovation in the technical field in order to recognize the creativity of the invention, and does not 
protect the innovation of business methods. Japan's attitude is somewhere between the two. According to the national conditions and the creative evaluation criteria of the combined patent technology scheme, China can evaluate whether the technical features are combined to produce unexpected effects, refer to foreign practices, conduct a comprehensive evaluation, draw a creative conclusion and formulate a detailed review standard.

\subsection{Other measures}

In addition to the above improvement measures, the protection system for business model patents can also be improved from the following aspects:

First, improve the professional quality and professional level of patent examiners. The business level and working ability of existing examiners can be improved through training and evaluation. In addition, a large number of compound talents with various professional knowledge backgrounds can be cultivated to enrich the patent examiner team. Second, establish a complete information database for patent examination of business models. Measures should be taken to establish a comprehensive and complete business model information database, and the content of the database should be continuously supplemented by the main bodies such as the Patent Office and Internet companies to enrich the content of the database. Third, carry out international cooperation and exchanges, and learn from the experience of developed countries to improve China's business model patent protection system. Strengthen legislation and information exchanges with countries and regions with fast-developing business model patents such as the United States, the European Union, and Japan, and promote joint search and resource sharing of business model data.

\section{CONCLUSION}

The Internet + business model has a huge impact on innovation, and the future competition of business model innovation will also become the core of competition among enterprises. At present, the patent protection of the business model has already emerged as early as dawn. I look forward to continuously strengthening the legislative protection of business model patents in the future, taking into account various factors, creating new types of intellectual property rights and response rules, further improving the protection system of business model patents, and protecting the patent protection of business models under the Internet + background convoy.

\section{ACKNOWLEDGMENT}

This research was financially supported by Guangxi Science and Technology Development Strategy Research Project "Science and Technology Project and Patent Agency System Research" (No.GK.ZL18077014) and the Innovation Project of Guilin University of Electronic Technology Graduate Education (No.2020YCXS106) and Guilin University of Electronic Science and Technology Internet + Intellectual Property Rights Protection Research Think Tank (Guidian Science [2019] No.3).

\section{REFERENCES}

1. ANDROUTSOS A, Access link bandwidth externalities and endogenous internet growth: a long run economic approach, International Journal of Network Management, 2011, pp. 21-24.

2. Chen Shuyun, Tao Yunqing. "Internet +", inclusive finance and technological innovation: impact mechanism and empirical evidence, Science and Technology Progress and Countermeasures, 2019, pp. 17-24.

3. Wu Shixuan Rong, Zhang Wensong. Research on the Factors Influencing the Initial Success of Chinese Internet Enterprises, Science and Technology Progress and Countermeasures, 2019, pp. 1-8.

4. Kulins, C., Leonardy, H., \& Weber, C. A configurational approach in business model design, Journal of Business Research, 2016, pp. 1437-1441.

5. Moehrle, M. G., Wustmans, M., \& Gerken, J. M. How business methods accompany technological innovations-a case study using semantic patent analysis and a novel informetric measure, $R \& D$ Management, 2018, pp. 331-342.

6. Yun, J. J., Won, D., Jeong, E., Park, K., Yang, J., \& Park, J. The relationship between technology, business model, and market in autonomous car and intelligent robot industries, Technological Forecasting and Social Change, 2016, pp. 142-155.

7. Annabeth Aagaard, Sofia Ritzén. The critical aspects of co-creating and co-capturing sustainable value in service business models, Creativity and Innovation Management, 2020, pp. 292-302.

8. Milan Jocevski, Niklas Arvidsson, Antonio Ghezzi. Interconnected business models: present debates and future agenda, The Journal of Business \& Industrial Marketing, 2020, pp. 1051-1067. 